\title{
Emboles septiques secondaires à une endocardite à Kingella kingae
}

\section{Septic embolism dues to Kingella kingae endocarditis}

\section{Michel · S. Dautheville $\cdot$ P. Ray}

Reçu le 24 septembre 2013; accepté le 5 novembre 2013

(C) SFMU et Springer-Verlag France 2013
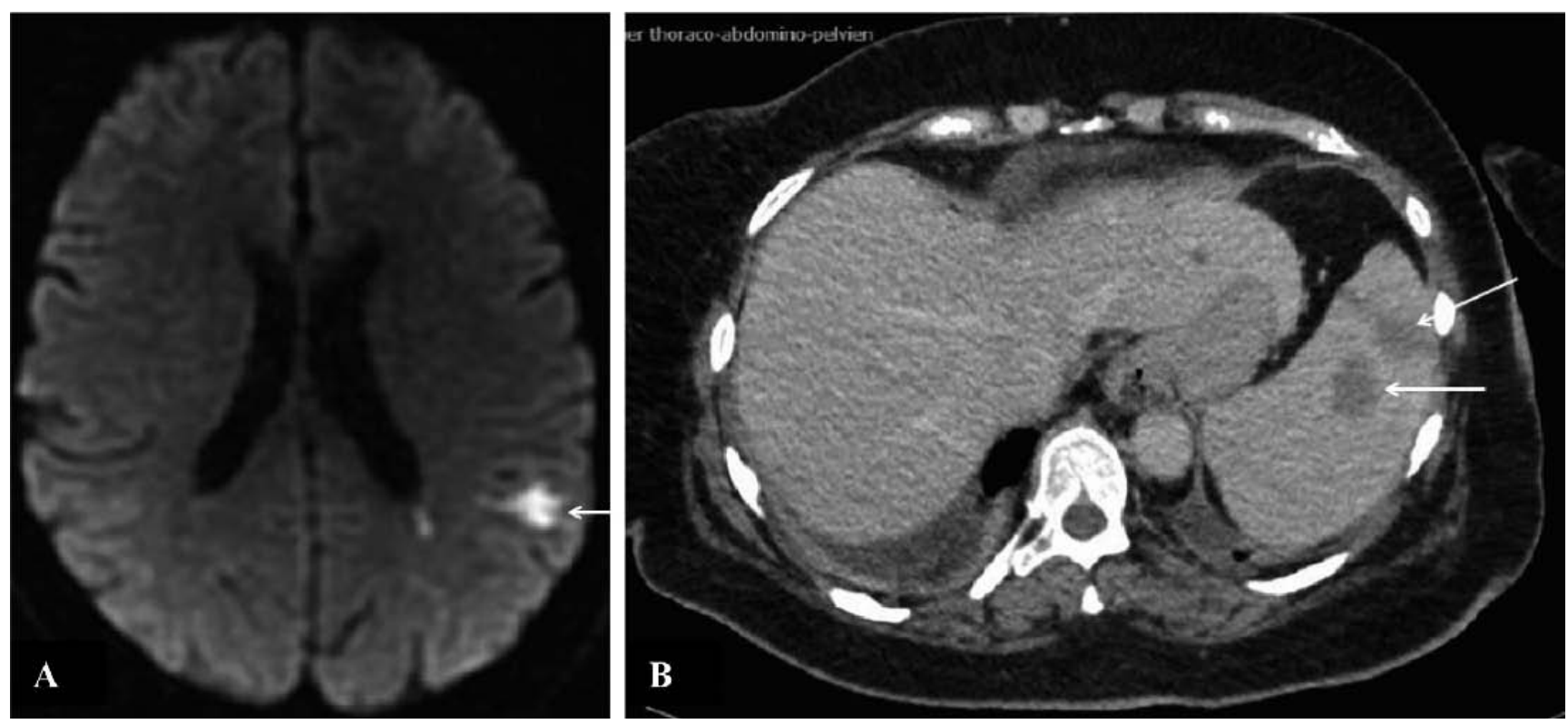

Fig. 1 A : IRM cérébrale en séquence de diffusion montrant un hypersignal révélant un embole septique (flèche) ; B : scanner abdominal révélant deux hypodensités (flèches) dans la rate

Une patiente de 66 ans se présente au service des urgences pour confusion et manque du mot apparus dans la matinée, dans un contexte fébrile. Il existait un syndrome inflammatoire et le scanner cérébral non injecté ne détectait aucune anomalie. La ponction lombaire a retrouvé une formule panachée (40 éléments) sans germe identifié. Les images de l'IRM (Fig.1 A) puis du scanner corps entier ont retrouvé des emboles septiques multiples intracérébraux et spléniques (Fig. 1B). Il s'agissait d'une endocardite aortique à Kingella

M. Michel · S. Dautheville $\cdot$ P. Ray $(\bowtie)$

Service d'accueil des urgences, CHU Tenon,

Assistance publique-hôpitaux de Paris, 4, rue de la Chine,

F-75020 Paris, France

e-mail : patrick.ray@tnn.aphp.fr

Université Pierre et Marie Curie, 4, place Jussieu, F-75005 Paris, France kingae, germe du groupe HACEK à croissance lente. Malgré l'antibiothérapie et la chirurgie précoce, l'évolution a été défavorable après un accident vasculaire hémorragique postopératoire fatal.

Ce dossier rappelle l'importance de penser à une endocardite (rare en médecine d'urgence) devant l'association fièvre et/ou contexte infectieux avec des emboles systémiques multiples. Comme dans le cas présent, il est alors nécessaire de préciser au bactériologiste de garder en culture les flacons d'hémoculture de façon prolongée [1].

\section{Référence}

1. Houpikian P, Raoult D (2003) Diagnostic methods. Current best practices and guidelines for identification of difficult-to-culture pathogens in infective endocarditis. Cardiol Clin 21:207-17 